\title{
DOI: 10.18523/lcmp2522-9281.2019.5.52-62
}

Іванна Цар

https://orcid.org/0000-0002-9764-5758

\section{ПРОБЛЕМА ОФІЦИЙНОЇ ДВОМОВНОСТІ ОЧИМА МОЛОДИХ РОСІЙСЬКОМОВНИХ ВИХІДЦІВ ІЗ КРИМУ ТА ДОНБАСУ}

V статті на матеріалі інтере 'ю проаналізовано погляди молодих вихідиів із Луганської, Донечькой областей та Криму на проблему офічійной двомовності. 3'ясовано, що російськомовна молодь переважно заперечує потребу надання російській мові статусу офічійної. Головним аргументом молодих людей с йня належність до Украйнської держави. Виявлено, щъо молодь здебільшого не ознайомлена з украйнським мовним законодавством і легко піддасться впливу ЗМІ.

Ключові слова: офіційна двомовність, російськомовна молодь, переселенці, статус мови, державна мова, ставлення до мови.

\section{Ветуп}

Проблема мовного законодавства часто є предметом політичних маніпуляцій в українському суспільстві. Прийняття Закону України «Про забезпечення функціонування української мови як державної» спричинило різкий спротив проросійських політичних сил, які обгрунтовують свою позицію тим, що цей Закон, на їхню думку, порушує права російськомовних, і продовжують пропагувати, якщо і не прямо, як це було раніше, ідею офіційної двомовності.

\section{Теоретичне підгрунтя}

Навколо статусу мов неодноразово точилися дискусії. Мовознавці та юристи намагалися з'ясувати сутність понять «офіційна» $\mathrm{i}$ «державна». Як зазначає В. Радчук, «зрештою, хтось залишився при думці, що офіційна мова "не дотягує" до державної, але більшість, схоже, дійшла згоди, що в застосуванні до наших умов офіційна і є державною. Конституційний Суд України ці поняття зрівняв» (Радчук, 2007, с. 151). Попри намагання деяких політиків спекулювати на темі офіційної двомовності, соціолінгвістичні дослідження доводять, що ні українськомовні, ні російськомовні, 
ні ті, хто послуговуються обома мовами залежно від ситуації, переважно не вимагають якогось особливого статусу для російської мови. На це вказують дані дослідження мовної ситуації в Україні за підтримки програми INTAS (серпень 2006 - липень 2008) (Масенко, 2008, с. 109), опитування громадської думки киян, проведеного Г. Залізняк у 2012 р. (Залізняк, 2014, c. 182), дослідження мовної ситуації України за підтримки фонду Фоль-

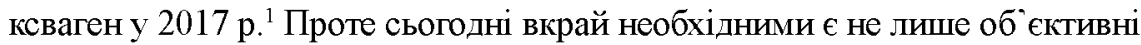
кількісні дані, а й результати якісних соціолінгвістичних досліджень, які б продемонстрували ставлення до офіційної двомовності представників різних груп мовців, зокрема російськомовної молоді зі сходу та Криму, що відчула на собі наслідки війни та окупації.

Метою цієї наукової розвідки $\epsilon$ аналіз поглядів молодих вихідців iз Донбасу та Криму, які проживають і навчаються в м. Києві, на проблему офіційної двомовності.

\section{Методи та матеріал дослідження}

Для опрацювання матеріалу застосовано метод мовної біографії, що, за визначенням Н. Шумарової, передбачає опис мовного життя людини з урахуванням ії мовної поведінки, мовних потреб і преференцій (Шумарова, 2012, c. 123) і який використовують у нау кових розвідках соціолінгвісти (І. Брага, В. Чемес) та діалектологи (П. Грищенко, М. Лесюк). У рамках дослідження проведено 20 інтерв 'ю, в яких інформантів запитали: Чи потрібна в Украйні офіційна двомовність? Опитано респондентів віком 17-28 років, шо перебувають у Києві від одного року й подеколи відвідують родичів у рідних регіонах. Усі вони в повсякденні послуговуються російською мовою². Записи інтерв'ю розшифровано зі збереженням граматики інформантів.

\section{Узагальнений соціально-психологічний портрет респондента}

Використання методу мовної біографії дало змогу отримати інформацію про мовні преференції, мовну поведінку респондентів-переселенців, мовну ситуацію в їхніх рідних регіонах і в Києві та, відповідно, узагальнити їхні соціально-психологічні риси. Перед нами молодь, яка переїхала

1 Дослідження виконано в рамках трирічного проекту «Вi- and multilingualism between conflict intensification and conflict resolution. Ethno-linguistic conflicts, language politics and contact situations in post-Soviet Ukraine and Russia» AZ № 90217.

${ }^{2}$ Незважаючи на те, що всі опитані визнали себе російськомовними, дехто з них давав інтерв`ю повністю українською, ще кілька переходили на українську, відповідаючи на певні запитання. 
3 окупованих або близьких до окупованих територій і безпосередньо стикалася $з$ реаліями життя в умовах «русского мира». Їі мислення ще перебуває під сильним впливом домінантного оточення. 3 іншого боку, це молоді люди, які переважно народилися і виросли в незалежній Україні, мали змогу здобути українську середню освіту (у деяких випадках частково), мають доступ до необмежених джерел інформації в мережі інтернет i, відповідно, мають дещо інші погляди на проблеми, пов 'язані 3 мовою, ніж їхні батьки. 3 матеріалів інтерв ю бачимо, що вони нерідко протиставляють себе своїм батькам і загальному оточенню міст чи містечок, у яких виросли. Так, інформантка Н. (м. Стаханов, Лугансыка обл.) зазначає, що батьки були проти ії переїзду до Києва. Крім того, дівчина мала труднощі з підготовкою до $3 \mathrm{HO}$ з української мови та літератури, оскільки українську в школі не викладали від початку окупації, тому рішення про переїзд не було легким. Інша інформантка Л. (м. Маріуполь, Донецька обл.), батьки якої позитивно сприймають українську владу, так оцінила своє середовище в Маріуполі: Просто некоторые сложно воспринимают [українську мову] // Им непонятно // Особенно вот между прочим даже не мое поколение / а старие // Вот вообще сложно все идет // А мне типа вообще легко // Я вообще не парюсь // Ну на украинском / на русском // Или / например / там кто-то что-то читает / «Ой как мне сложно!» «Ой как тяжсело!» Я думаю / "Ну что тут тяжёлого?!» / Я воспринимаю одинаково и то / и то // Просто в нас люди вот / уменя / они настроены немного так агрессивно // Как будто их заставляя-яют / как будто их ну блин... Для розуміння мотивів конкретного ставлення до мови необхідно заглибитися у мовну біографію кожного з опитаних. Погляди інформантів відрізняються залежно від виховання, політико-ідеологічних переконань батьків, соціальної ситуації в сім'ї і регіоні загалом, а також від усвідомлення своєї національної належності.

\section{Ставлення російськомовної молоді до офіційної двомовності}

Основні аргументи мовців щодо проблеми офіційної двомовності систематизовано у 9 груп за ключовими тезами відповідейз

1. Вагасться. Хай про всяк випадок буде прописано, що в нас дві офіційні мови, щоб російськомовних не принижували.

\footnotetext{
${ }^{3}$ Приклад використання такого прийому див.: (Bellet, 2016).
} 
Х. (19 р., м. Старий Крим, Крим) Сложный вопрос какой-то // Ну я думаю / конечно это нормально / что два языка в стране / но... если это Украина / понятное дело / документачия должна быть на украинском / программа икольная хотя бы приближённо на украинском // Если люди живут тут / то думаю / что они должны понимать элементарно там / как написать заяву какую-то // Ну это нормально // Но если ограничить / допустим / употребление русского языка / то / я думаю / был бы какойто бунт // В любом случае люди...

$\mathrm{I}^{4}$. Що ти маєи на увазі «ограничить употребление русского языка»?

Х. Ну вот просто / просто оставить украинский и всё// Мало того / что там да / прописано

I. Ну от зараз тільки украйнська прописана // То ти вважсаєи / що зараз ограничивают русский?

Х. А да? А счас так? (сміється) Ну вообще я думаю / лучие пусть это будет прописано / что два языка / чем вот так //

У розумінні інформантів цієї групи функції державної мови зводяться здебільшого до офіційного вжитку. 3 одного боку, Н. погоджується, що якщо ми живемо в Україні, то офіційна сфера має бути українською, з іншого - підсвідомо має перманентний страх заборони російської, хоча не вважає, що російську мову в Україні обмежують чи принижують.

2. Вагасться. Треба враховувати російськомовне населення, але всі повинні прагнути до однісї мови.

К. (17 р., м. Краматорськ, Донецька обл.) Я затрудняюсь // С одной стороны это прекрасно / что у нас есть этот язык украинский / государственный / но нужно брать во внимание / что в Луганской и Донечкой областях в основном / практически все / больиинство / это русскоговорящие люди // И-и-и это было бы немного так / грубо говоря / нечестно / да / вводить один язык // Но и тоже вводить два / и украинский / и русский... не знаю // Все мы должны стремится к одному языку / я считаю / украинскому //

Для мовців цієї групи питання мови постає перш за все 3 прагматичного боку. Молодь зазначає, що це питання $\epsilon$ складним, і вагається у висловленні якоїсь чіткої позиції. Аргументом на користь офіційної двомовності є прагнення "догодити всім», щоб не образити. Проте певні проблиски вияву національної свідомості все-таки можна помітити. Зауважмо,

${ }^{4}$ I. - тут і далі - інтерв`юер. 
молоді люди постійно наголошують, що якщо ми живемо в Україні, то українська мова повинна бути державною. Але їх влаштовує стан, коли державною вона є тілыки на папері. Водночас підкреслюють, що в перспективі має бути єдина мова - українська. Слушно зауважує В. Васютинський, пишучи, що російськомовні мешканці сходу і півдня України настільки толерантно ставляться до українськомовності, наскільки це не зачіпає їхніх особистих інтересів (Васютинський, 2002, с. 76). На його думку, неприхильність до української більше зумовлена соціально-психологічними настановами, ніж політико-ідеологічними. Проте, аналізуючи матеріали інтерв $ю$, можемо з впевненістю говорити, що за 17 років ситуація таки дещо змінилася: російськомовна молодь вагається між прагматичними й ідеологічними мотивами, а те, які з них можуть перемогти, все більше залежить від впливу освіти та засобів масової інформації.

3. Вагасться. Хай люди самі вибирають.

С. (18 р., м. С.лов'янськ, Донецька обл.) Я за полную федерализацию // Ну за полную свободу людей // Чтоби они сами выбирали / что они будут делать // Я в принципе против госрегулирования // госзапретов // Ну как сказать // По сути / то что они [влада] делали два языка / это... так само как в айти / сделали б / например / все языки доступными // Ну только / например / в государственном секторе все-таки оставить украинский потому что это язык народа //

Р. (17 р., м. Маріуполь, Донецька обл.) Ну якось нейтрально // Ну в різних куточках Украйни спілкуються різними мовами // Тож... Ну че вибір людей, які там живуть

Інформанти цієї групи розглядають проблему офіційної двомовності з погляду «дозвіл - заборона» розмовляти певною мовою. 3 одного боку, їхні настанови є дещо схожими 3 позицією представників попередніх двох груп. Проте тут на першому плані концепція свободи вибору, заперечення будь-яких обмежень. Таке протестне ставлення до всього нав'язаного згори характерне для молоді як вікової категорії загалом.

4. Не потріб̆о. Оскільки ми живемо в Украйні, то мас бути державною українська мова.

А. (17 р., м. Луганськ) Ну вообще это сложный вопрос // Если так подумать / то Украина.. в Украине должен быть в приницие украинский язык // Но если считать вот эту всю документацио / которая кому-то 
может быть сложна на украинском языке / то в принципе возможно Но при этом / если / например / только украинский язык останется офиииальным / то это не мечает же тебе говорить на русском языке //

I. Тобто твос ставлення до офіиійной двомовності..?

А. Двояке такое // Это не особо нужно / я думаю /

С. (18 р., м. Алчевськ, Луганська обл.) Важке питання // Мені здається / якцо в нас вже Украйна / то і мова державна повинна бути одна / українська //

Для інтерв’юйованих цієї групи мова асоціюється 3 державою. Цікаво, що на інше питання з цього ж інтерв ю - Чи погоджустеся Ви з думкою, ио мова - че символ держсав? - всі без винятку опитані відповіли ствердно.

\section{5. Не потрібно. Все одно буде тільки одна мова.}

В. (28 р., м. Лутугіне, Луганська обл.) Це зовсім неправильний підхід // Тому що якио дозволити і одне / $і$ іние / то буде щиось одне // Тобто якио можсна робити щось легше і щось складніме / то будуть робити те / що легше // Oт як наші викладачі / які там бурчали з-за украйнськой мови / невдоволення своє виказували // Нарікали / «Навішо це треба? Bci підручники російськомовні! Всі радянські в нас підручники!» Om // «A лекції украӥнською робити!» Ну вони все одно за декілька місячів перевели лекції на украйнську мову $і$ читають / і нормально / і че корисно // Oт // I нам один викладач казав / який передовий в чьому був / ио ивидие за всіх зробив / каже / він і у Францій лекції читав французькою мовою / буквально за десять місяців вивчив ирю французьку ну до такого рівня / що можна було читати лекції / каже / ио треба розвивати просто себе //

А. (17 р., Крим) Ну смотрите // У нас [в Криму] хоть три официальных языка / но-о-о... В Крылу идет только один // Нет ни крылскотатарского / ни украинского / ни в иколе / ни где-то еще // Мне кажстея / хватает и одного // Если ты знаешь еще какой-то язык / молодеч// Но если у тебя как бы в стране есть уже какой-то определенный язык / ты должен на нем понимать / разговаривать / слуиать и еще чmo-mo

Погляди опитаних цієї групи збігаються з думками мовознавців. Зокрема, Б. Ажнюк наголошує: «За умов рівного статусу реальну перевагу має мова 3 потужним інституційним, соціальним та інформаційним ресурсом» (Ажнюк, 2014, с. 30). 
Інформанти не лише заперечують необхідність упровадження двох офіційних мов, а й вбачають користь у розширенні функціонування української мови. Збереження за українською мовою статусу єдиної державної є стимулом до опанування цієї мови. За результатами дослідження мовної ситуації в Україні (за підтримки програми INTAS, серпень 2006 липень 2008), державний статус української мови сприяє підвищенню iï престижу (Масенко, 2008, с. 110).

6. Не потрібно. Ситуація зараз нормальна.

А. (18 p., Маріуполь, Донецька обл.) Мне кажется / офіційио щзось там вводити... зачем надо? Ну люди все... Мы живем как бы в Украине люди давно уюе говорят на русском языке // Как удобно / пусть так и разговаривают / хоть на украинском / хоть на русском // Всем как удобно / так и говорят // Никто за то / что ты на русском языке говорииь / тебя палками не бьет // За то / что на украинском / тебя тоже никто палками не бьет // Мы ж не в Америке / где ты сказал на русском и тебя никто не понял // Все понимают друг друга //

Респонденти цієї групи оцінюють реальний стан функціонування обох мов у своїх рідних регіонах і їхній статус як задовільні. Підтримка української як єдиної мови тут виявляється радше як вияв інертності, байдужості до стану мови у суспільстві. Це той випадок, коли говорять, що проблема мови не на часі.

7. Не потріб́но. Російська й так переважас в російськомовних регіонах.

О. (27 p., Донецьк) Ну я ставлюся так / щүо якщо хтось не знає однієї мови / то скільки там додаткових мов не вводь / то він і на другій нічо не нanume //

I. Тобто Ваие ставлення / позитивне / негативне /неитральне?

O. Ну-у / чесно кажучи / навіть не знаю // У нас / наприклад / більшість усього була російською мовою // В нас там і дисертації.. То все робилося навіть на російській мові // Навіть зараз в нас хтось захицався / по-моєму.. Ну тойсть фактично украйнською мовою велися там / не знаю / тільки паспорт / щче якісь пару документів / і тому я не бачу великого такого переляку / щоб була тільки одна державна мова // Ну як би більиість всяких там документів і так були російською мовою // I так кругом була російська мова.. В иколі / в інституті // (сміється) Навпаки / иоб знайти украйнську мову / то треба було ще пошукать // Томуя не бачу в тому сенсу// 
Інформанти цієї групи вважають надання російській мові офіційного статусу нелогічним, оскільки вона домінує де-факто в регіонах, що є об єктом аналізу. Натомість констатують, що на цих територіях реально не втілюється державний статус української мови, підкреслюючи декларативність українського мовного законодавства. У ситуації, коли державний статус української мови не має реального сенсу, будь-які спроби надати офіційний статус російській мові $€$ необгрунтованими, бо стають у таких умовах юридичним утвердженням одномовності.

8. Не потрібно. Має бути одна мова- українська, бо вона об'єднус.

Л. (18 р., Маріуполь, Донецыка обл.) Нет // Мне кажсется / что это неправильно //

I. A чому?

Л. Ну потому что должен быть один язык // У нас и так слишком... Язык он как бы объединяет людей // Я так считаю // Один // А так унас... Ну что это? Это неправильно //

Мова постає як чинник консолідації нації.

9. Обидві мови уже с державні.

Із проведених інтерв'ю зрозуміло, що молодь нерідко не лише не розуміє сутності поняття «державна мова», а й майже нічого не знає про мовне законодавство. Дехто з опитаних узагалі не орієнтується, який статус мають українська і російська мови в рідних регіонах, уважаючи, що вони обидві є державними:

Н. (18 р., Стаханов, Луганська обл.) В Луганской области русский $и$ украинский язык у нас государственные языки // Но-о-о как-то стараются его [українську] меньие использовать / хотя в школах его преподают / но ему стали меньие уделять внима-а-ния // То есть там... Унас даже проводятся олимпиады по украинскому языку // Его не притесняют / но просто люди стали его меньие использовать

I. А чому? Після того / коли прийняли регіональною?

Н. Э-э-э да // После этого / да// Ну больие стали относится... Выие стали русский язык //

I. A чому так? Як ти думаси?

Н. Ну-у-укак бы... Унас это больие такой язык... Люди просто больше говорят и стараются уделять внимания правильной речи русского языка // То есть если он у нас не родной / украинский язык / в нашей местности не употребляется очень иироко // Поэтому стали люди 
уделять больие внимания русскому языку / чтоб хотя бы на русском языке люди говорили... правильно и грамотно //

Спостерігаємо нівелювання семантичних зв'язків між поняттями «державна мова» i «держава». Пересічна молода людина, не ознайомлена з реальним, юридично зафіксованим статусом мови, вважає державною мову повсякденного спілкування. Поняття «державна мова» / «рідна мова» / «мова повсякденного спілкування» тут стоять в одному ряду.

Доходить до того, що деякі опитані розуміють офіційну двомовність не як запровадження, крім української, ще й російської мови офіційною, а навпаки - запровадження української мови.

Водночас варто звернути увагу, що інтерв'юйовані самі констатують факт: запровадження двох офіційних мов фактично ще більше звужує функціонування української мови там, де її використання й раніше було мінімізоване.

\section{Висновки}

Хоча наше дослідження не $\epsilon$ кількісним і не претендує на статистичну достовірність, факт, що 15 із 20 опитаних негативно оцінили офіційну двомовність, лише п'ятеро висловили сумніви в доцільності цієї ідеї й ніхто, не вагаючись, не підтримав, вважаємо показовим. Російськомовна молодь, яка виросла у повністю російськомовних регіонах, здебільшого усвідомлює об'єднавчу та державотворчу функції української мови. Це молодь, якою вже не так легко маніпулювати не лише в питаннях мови, а й взагалі. Однак досі спостерігаємо наслідки критичної необізнаності молодих людей із реальним станом речей у сфері мовного законодавства і його впливу на повсякденне використання мов.

Отже, постає необхідність розвіяння стереотипів, протидії маніпуляціям політиків та ЗМІ на тему мови, роз'яснення ключових позицій мовного законодавства, виховання національної свідомості, розширення українськомовного середовища. Це наукова розвідка демонструє нагальну потребу проведення цільових кількісних соціолінгвістичних досліджень у середовищі російськомовної молоді сходу та півдня України, а також напрацювання та втілення заходів щодо поступової інтеграції цих молодих людей в український мовно-культурний простір. 


\section{Список використаной літератпри}

Ажнюк, Б. (2014). Проблема мовних прав у сучасній лінгвістиці. В Мовні права в сучасному cвimi (с. 22-36). Ужгород.

Васюоинський, В. (2002). Українська ідентичність російськомовних: між відчуженням і долученням. В Мовні конфлікти і гармонізауія суспільстеа (с. 74-80). Київ.

Залізняк, Г. (2014). Статус української та російської мови у дзеркалі громадської думки киян. В Мовні права в сучасному світі (с. 176-185). Ужгород.

Масенко, Л. (2008). Мовна ситуація України: соціолінгвістичний аналіз. В Мовна політика та мовна ситуація в Україні (с. 96-131). Київ: Видавничий дім «Києво-Могилянська академія).

Радчук, В. (2007). Параметри і взаємодія мов. В Двомовність: зміиуяання та взаємодія мов (c. 121-158). Київ: Пульсари.

Шумарова, Н. П. (2012). Социолингвистика Украины: постсоветский период. Вопросы языкознания, 6, 123-138.

Bellet, S. (2016). Sprachenportraits - ein introspektives Instrument für das eigene Spracherleben. Retrieved from https://www.ph-vorarlberg.ac.at/fileadmin/user_upload/RED_SOZ/PDFs/SBellet_ Sprachenportraits.pdf.

\section{References}

Azhniuk, B. (2014). Problema movnykh prav u suchasnii linhvistytsi [The problem of language rights in modern linguistics]. In Movni prava v suchasnomu sviti [Language rights in the modern world] (pp. 22-36). Uzhhorod [in Ukrainian].

Bellet, S. (2016). Sprachenportraits - ein introspektives Instrument für das eigene Spracherleben. Retrieved from https:/www.ph-vorarlberg.ac.at/fileadmin/user_upload/RED_SOZ/PDFs/SBellet_Sprachenportraits.pdf.

Masenko, L. (2008). Movna sytuatsiia Ukrainy: sotsiolinhvistychnyi analiz [The language situation of Ukraine: sociolinguistic analysis]. In Movna polityka ta movna sytuatsiia v Ukraini [Language Policy and Language Situation in Ukraine] (pp. 96-131). Kyiv: Vydavnychyi dim "Kyievo-Mohylianska akademiia" [in Ukrainian].

Radchuk, V. (2007). Parametry i vzaiemodiia mov [Parameters and interaction of languages]. In Dvomovnist: zmishuvannia ta vaaiemodia mov [Bilingualism: Mixing and Interaction of Languages] (pp. 121-158). Kyiv: Pulsary [in Ukrainian].

Shumarova, N. P. (2012). Sotsiolingvistika Ukrainy: postsovetskiy period [Sociolinguistics in Ukraine]. Voprosy yazyikoznaniya [Linguistics issues], 6, 123-138 [in Ukrainian].

Vasiutynskyi, V. (2002). Ukrainska identychnist rosiiskomovnykh: mizh vidchuzhenniam i doluchenniam [The Ukrainian identity of Russian speakers: between alienation and attachment]. In Movni konflikty i harmonizatsiia suspilstva [Language conflicts and the harmonization of society] (pp. 74-80). Kyiv [in Ukrainian].

Zalizniak, H. (2014). Status ukrainskoi ta rosiiskoi movy u dzerkali hromadskoi dumky kyian [Status of Ukrainian and Russian in the mirror of Kyiv citizens public opinion]. In Movni prava $v$ suchasnomu sviti [Language rights in the modern world] (pp. 176-185). Uzhhorod [in Ukrainian]. 
Ivanna Tsar

\section{Abstract}

\section{THE PROBLEM OF OFFICIAL BILINGUALISM FROM THE POINT OF VIEW OF YOUNG RUSSIAN SPEAKING NATIVES FROM CRIMEA AND DONBAS}

Background. The problem of official bilingualism in Ukraine is constantly at the center of political speculation, although, according to recent sociolinguistic studies. Russian-speaking people mostly do not require special status for the Russian language.

Purpose. The purpose of this article is to analyze the views of young natives from Donbass and Crimea, who live and study in Kyiv, on the problem of official bilingualism.

Methods. The methods of language biography and interview. which are used by sociolinguists and dialectologists to study linguistic personality, are applied in the paper.

Results. Most of the respondents believe that in Ukraine there is no need to officially introduce bilingualism. since the situation is normal; will still be only one language; Russian already prevails in Russian-speaking regions; we live in Ukraine, so only Ukrainian should be the state language; the Ukrainian language unites people; both languages are already state. The rest of the respondents could not clearly express their attitude to this problem, saying that. on the one hand. it is necessary to be guided by the people's desire, to introduce official bilingualism just in case, in order to the Russian-speaking people should not be humiliated; and, on the other hand, to strive for one language Ukrainian.

Discussion. Russian-speaking youth is mostly aware of the Ukrainian language unifying and state-building functions. but it does not really distinguish the terms «official» and «state», is not familiar with Ukrainian language legislation, and is influenced by the media. The article reveals the need for quantitative sociolinguistic researches in the Russian-speaking youth environment.

Keywords: official bilingualism. Russian-speaking youth. migrants. status of language, state language, attitude to language. 